\title{
Mortality and the concurrent ingestion of food and saccharin in rats
}

\author{
ANDREW STROUTHES \\ State University of New York, Binghamton, New York 13901
}

\begin{abstract}
Rats drinking freely $1.0 \%$ sodium saccharin solution and eating a reduced food ration, whether mixed $(5.0 \%)$ or not with saccharin, lost body weight and died. Death depended neither on the absolute saccharin amount per gram of body weight nor on the nonconcurrence of saccharin and food ingestion, but instead, depended on the saccharin and the intermeal interval. Saccharin animals died on the $20 \mathrm{~g} / 48 \mathrm{~h}$ and the $10 \mathrm{~g} / 24 \mathrm{~h}$ food regimens and did not die on the $5 \mathrm{~g} / 12 \mathrm{~h}$. Rats did not die on any schedule if they ate food and drank water only. The behavioral consequences of saccharin and its potential harm to all animals, and to those on a reduced diet in particular, were emphasized.
\end{abstract}

Sodium saccharin $\left(\mathrm{C}_{7} \mathrm{H}_{4} \mathrm{NNaO}_{3} \mathrm{~S} \cdot 2 \mathrm{H}_{2} \mathrm{O}\right)$ is a sweet-tasting nonnutritive substance. These properties have made it, in contrast to sucrose, ideal for studying reinforcement, taste preference, and other related issues. Saccharin has also been considered to be free from other postingestional consequences as well (Folin, 1914; Herter, 1910), despite the more recent evidence from several experiments using animals and humans which showed that it has strong physiological (Beebe-Center, Black, Hoffman, \& Wade, 1948; Bunde \& Lackey, 1948; Carlson, Eldridge, Martin \& Foran, 1923; Haramaki, 1922; Kun \& Istvan, 1947; Strouthes, 1970; 1973; Valenstein, 1966; Valenstein \& Weber, 1965; Volo \& Strouthes, 1974; Warren \& Warren, 1966) and behavioral (Strouthes, 1970; 1973) consequences. Just recently, of course, a Canadian study (Arnold, Moodie, Grice, Charbonneau, Stavric, \& Munro, Note 1) linked saccharin to bladder cancer in rats ingesting saccharin, thus supporting the earlier results of Bryan, Erturk, and Yoshida (1970) showing bladder carcinomas when saccharin was surgically implanted in the bladder of mice. Strouthes (1973) and Volo and Strouthes (1974) linked saccharin to death in animals fed reduced food rations. The present experiment is an extension of these studies. It examined the effects of saccharin in food-deprived rats.

Earlier studies (Strouthes, 1973) and numerous unpublished replications and variations of these showed that rats and mice on a reduced food ration, $10 \mathrm{~g} / 24 \mathrm{~h}$, and saccharin solution ate all of their food roughly within 90 min of feeding, drank large amounts of saccharin solution, lost body weight, and died. Both weight loss and death rate depended on

Thanks are extended to Ronald Levine and Judith Dunetz, who assisted in collecting data for Experiments 1 and 2, respectively. the saccharin solution concentration (Strouthes, 1973) and not on the excessive amounts of fluid (Volo \& Strouthes, 1974). Controls, i.e., animals which were given the same food ration but water instead of saccharin solution, also ate all of their food within a short period, but drank smaller amounts of water than their counterparts drank saccharin, lost less body weight, and did not die (Strouthes, 1973). Animals offered a choice of saccharin solution and water ignored the water, drank the saccharin solution, and, like the animals which were given only saccharin solution, they too lost body weight and died. The experiments also showed that the saccharin consumptions fluctuated periodically. In addition, the mean amplitude and frequency of these fluctuations were positively related to saccharin concentration. This evidence was consistent with the findings from earlier experiments and supported the position that (1) saccharin caused systemic stress and, that (2) fluctuations represented attempts to accommodate the saccharin and thus relieve the system in the homeostatic sense. Indeed, animals which exhibited the fluctuations tended to live longer than those which did not. Also, the rats which did not drink very large amounts of saccharin, and those which increased their saccharin intakes very gradually as opposed to those which began by drinking large amounts, tended to survive (Strouthes, 1973). Finally, the experiments showed that fluctuations in saccharin intake and mortality were influenced by the length of the intermeal interval. With food rations constant $(10 \mathrm{~g} / 24 \mathrm{~h})$, it was found that increasing the length of the interval between feedings $(20 \mathrm{~g} / 48 \mathrm{~h})$ hastened mortality, while contracting the interval $(5 \mathrm{~g} / 12 \mathrm{~h})$ led to little or no apparent systemic strain. It was concluded that saccharin drunk on an "empty stomach" hastened mortality, while food in the stomach, at least once every $12 \mathrm{~h}$, caused reduction in both systemic stress and death. The 
present study examined mortality in rats which consumed their food and saccharin concurrently, as in a mixture of the two, i.e., saccharin-food. The concurrent consumption of food and saccharin was expected to reduce death. The study also investigated meal frequency in animals fed saccharin-food.

\section{METHOD}

\section{Subjects}

The subjects were 50 Sprague-Dawley albino rats derived from stock originally supplied by the Charles River Co., Mass. Thirty of these, 18 females and 12 males, were used in Experiment A. They ranged from 92 to 193 days of age and, for females and males, respectively, the mean body weights at the start of the experiment were 325 and $549 \mathrm{~g}$. The other 20 rats were used in Experiment B. They were female, 131 days old and averaged $315 \mathrm{~g}$. All animals were individually housed and tested in standard home cages in an air-conditioned vivarium $\left(21^{\circ} \pm 2^{\circ} \mathrm{C}\right)$ illuminated from 8:30 a.m. to 8:30 p.m. They had been reared on Purina Laboratory Chow (checkers) and tap water.

\begin{abstract}
Apparatus
Each home cage was fitted with either one or two Richter tubes through appropriate openings in the front wire mesh wall. Also fastened on the front cage-wall was one semi-circular stainless steel food bin $(10 \mathrm{~cm}$ long, $6 \mathrm{~cm}$ at its widest point, and $5.5 \mathrm{~cm}$ deep) used during testing for feeding the animals Purina Laboratory Meal (powder). The saccharin used to prepare the $1.0 \%$ saccharin solution was in crystal form and was purchased from Fisher Scientific, while the saccharin used to prepare the $5.0 \%$ saccharin-food was in powder form and was purchased from Sherwin-Williams. The solution was obtained by appropriately mixing volumes of deionized water $(W)$ with weights of saccharin $(\mathrm{sac} / \mathrm{sac}+\mathrm{W})$, while the saccharin-food was prepared by thoroughly mixing, in appropriate weights, food powder and saccharin powder ( $\mathrm{sac} / \mathrm{sac}+$ food).
\end{abstract}

\section{Procedure}

Matched for body weights and sex, the rats in Experiment $\mathrm{A}$ were assigned equally to six groups. Three groups received saccharin-food (SF), $21 \mathrm{~g} / 48 \mathrm{~h}$ for the male and $17 \mathrm{~g} / 48 \mathrm{~h}$ for the female, and $1.0 \%$ saccharin solution $(\mathrm{S})$, a choice of $1.0 \%$ saccharin solution or water (SvW), or water (W). The other three groups received food $(F), 20 \mathrm{~g} / 48 \mathrm{~h}$ for males and $16 \mathrm{~g} / 48 \mathrm{~h}$ for females, and again either $1.0 \%$ saccharin solution, a choice of $1.0 \%$ saccharin solution or water, or water. Accordingly, the six groups were labeled: 48SF-S, 48SF-SvW, 48SF-W, 48F-S, $48 \mathrm{~F}-\mathrm{SvW}$, and $48 \mathrm{~F}-\mathrm{W}$.

During the first 6 days of the experiment, all animals received 20 (or 16) $\mathrm{g}$ food every $48 \mathrm{~h}$ and unlimited tap water in bottles. Body weights, recorded just before feeding, formed the basis for assigning the $\mathbf{3 0}$ animals to the six groups.

Appropriate foods and fluids (in Richter tubes), were of fered on Day 7. Fluids were recorded and replenished daily while body weights were recorded bidaily just before feeding. The Richter tubes were emptied and freshly filled every other day. After about 5 days on the regimen, the food bins were, with one exception, licked clean. The exception was one overweight female, $539 \mathrm{~g}$ at the start of the experiment. This animal never ran out of food. It was also the only survivor in this group (see Table 1).

The rats in Experiment B were also matched for body weights. They were assigned to four groups of five each. All groups were fed $5.0 \%$ saccharin-food. Two of these were on $1.0 \%$ saccharin solution. One group was fed $8.5 \mathrm{~g}$ saccharin-food once $/ 24 \mathrm{~h}$, at $8: 30$ a.m., while the other was fed $4.25 \mathrm{~g}$ twice $/ 24 \mathrm{~h}$, at $8: 30 \mathrm{a} . \mathrm{m}$. and 8:30 p.m. The other two groups drank water, and again, they were fed either once or twice every $24 \mathrm{~h}$. The four groups were labeled: 24SF-S, 24SF-W, 12SF-S, and 12SF-W. In this experiment, no groups were offered a choice of saccharin-solution and water. Experiments A and B were conducted independently of each other. They were done 2 years apart, and A and B, respectively, were terminated after 72 and 60 days.

\section{RESULTS AND DISCUSSION}

Table 1 shows, for each group of the two experiments, the number of animals living and their mean percent body weights during each consecutive 12-day period, while panels A and B of Figure 1 show, for Experiments 1 and 2, respectively, the mean absolute saccharin consumptions ( $\mathrm{mg} / \mathrm{g}$ body weight) of the groups.

In Experiment $\mathrm{A}$, over $50 \%$ of the rats from each of the five groups whose food and/or fluid contained saccharin died within 48 days. Included among these was Group 48SF-W. These animals were not expected to die, certainly not so soon, because they

Table 1

Survivors and Their Mean Percent Body Weights Over Days, Experiments A and B

\begin{tabular}{|c|c|c|c|c|c|c|c|c|c|c|c|c|}
\hline \multirow[b]{2}{*}{ Groups } & \multicolumn{2}{|c|}{12} & \multicolumn{2}{|c|}{24} & \multicolumn{2}{|c|}{36} & \multicolumn{2}{|c|}{48} & \multicolumn{2}{|c|}{60} & \multicolumn{2}{|c|}{72} \\
\hline & $\begin{array}{c}\text { Number } \\
\text { Alive }\end{array}$ & $\begin{array}{c}\text { Mean } \\
\text { Percent } \\
\text { Body } \\
\text { Weight }\end{array}$ & $\begin{array}{c}\text { Number } \\
\text { Alive }\end{array}$ & $\begin{array}{c}\text { Mean } \\
\text { Percent } \\
\text { Body } \\
\text { Weight }\end{array}$ & $\begin{array}{l}\text { Number } \\
\text { Alive }\end{array}$ & $\begin{array}{c}\text { Mean } \\
\text { Percent } \\
\text { Body } \\
\text { Weight }\end{array}$ & $\begin{array}{l}\text { Number } \\
\text { Alive }\end{array}$ & $\begin{array}{c}\text { Mean } \\
\text { Percent } \\
\text { Body } \\
\text { Weight }\end{array}$ & $\begin{array}{l}\text { Number } \\
\text { Alive }\end{array}$ & $\begin{array}{c}\text { Mean } \\
\text { Percent } \\
\text { Body } \\
\text { Weight }\end{array}$ & $\begin{array}{l}\text { Number } \\
\text { Alive }\end{array}$ & $\begin{array}{c}\text { Mean } \\
\text { Percent } \\
\text { Body } \\
\text { Weight }\end{array}$ \\
\hline & \multicolumn{12}{|c|}{ Experiment $\mathrm{A}$} \\
\hline 48SF-S & 5 & 89 & 5 & 79 & 4 & 66 & 1 & & 1 & & 1 & \\
\hline 48SF-SvW & 5 & 89 & 5 & 78 & 5 & 64 & 0 & & 0 & & 0 & \\
\hline 48SF-W & 5 & 86 & 5 & 75 & 4 & 66 & 2 & & 2 & & 1 & \\
\hline 48SF-S & 5 & 88 & 5 & 79 & 2 & & 2 & & 0 & & 0 & \\
\hline 48F-SvW & 5 & 89 & 5 & 80 & 3 & 72 & 2 & & 1 & & 0 & \\
\hline \multirow[t]{2}{*}{ 48F-W } & 5 & 85 & 5 & 76 & 4 & 68 & 4 & 61 & 4 & 55 & 4 & 52 \\
\hline & \multicolumn{12}{|c|}{ Experiment B } \\
\hline 24SF-S & 5 & 88 & 5 & 80 & 5 & 73 & 1 & & 1 & & & \\
\hline 24SF-W & 5 & 86 & 5 & 82 & 5 & 75 & 5 & 69 & 5 & 64 & & \\
\hline $12 \mathrm{SF}-\mathrm{S}$ & 5 & 88 & 5 & 84 & 5 & 76 & 5 & 68 & 5 & 64 & & \\
\hline $12 \mathrm{SF}-\mathrm{W}$ & 5 & 88 & 5 & 84 & 5 & 77 & 5 & 73 & 5 & 68 & & \\
\hline
\end{tabular}




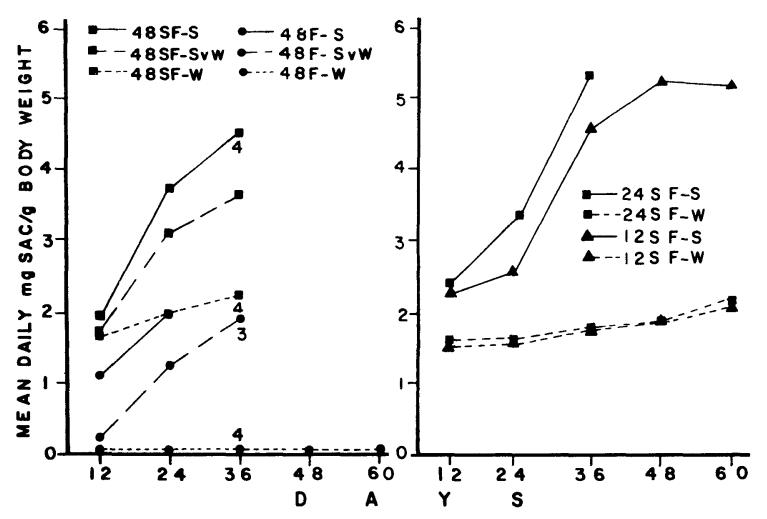

Figure 1 . Mean daily saccharin consumption (mg/g body weight) by the six groups in Experiment $A$ fed once every 48 h (Panel A) and by the four groups in Experiment $B$ fed either twice or four times every $48 \mathrm{~h}$ (Panel B). Beginning with five animals in each group, the numbers at points of the function represent survivors upon which each mean was based (see Table 1).

consumed their saccharin and food concurrently and also drank water instead of saccharin solution during the long intermeal intervals, conditions which were assumed to render saccharin least stressful to the organism. One animal $(20 \%)$ died in Group $48 \mathrm{~F}-\mathrm{W}$. It is the first time that an animal died and did so so early in the experiment by consuming water and reduced food of the quantities we have been using (Strouthes, 1973; Volo \& Strouthes, 1974; unpublished studies). Hunger is, therefore, discounted as the cause of death in this case.

Expectedly, body weights in all groups decreased over time, certainly for the first 24 days, $F(1,24)$ $=853.88, \mathrm{p}<.001$, but body weights did not differ due to saccharin consumptions, $F(5,24)=2.17$, $\mathrm{p}>.05$, even though the consumption differences were significant, $F(4,20)=7.10, p<.01$. Finally, there seemed to be no relation, beyond of course a minimal saccharin level, between the amount of saccharin $(\mathrm{mg} / \mathrm{g}$ body weight) and mortality. For example, the earliest and most frequent deaths occurred in $48 \mathrm{~F}-\mathrm{S}$, yet this group ingested less than $2 \mathrm{mg} / \mathrm{g}$ body weight while other animals, and particularly those from group 48SF-S, ingested almost twice the amount of saccharin/gram body weight and did not die until later, albeit by 12 days. Thus, it appears that a relatively small amount of saccharin, whether in fluid, in food or in both, is necessary and sufficient to cause systemic stress and death in animals fed one meal every $48 \mathrm{~h}$. Increases beyond this minimal value do not seem to increase the stress sufficiently to cause a change in the mortality rate. In summary, relatively small quantities of saccharin cause stress and death in animals on a 48-h feeding cycle whether or not the saccharin is consumed concurrently with food or between meals. In this regimen, since small quantities of saccharin produce near maximum stress (as reflected by the death frequency), larger saccharin amounts do not yield any appreciable increase in mortality. Conceivably, detection of finer stress variations if any exist, could be achieved by more appropriate physiological measures.

In Experiment $\mathrm{B}, 80 \%$ of the animals from Group 24SF-S died within 48 days while none died from any of the other three groups (Table 1). The saccharin consumptions per gram of body weight (Figure 1) clearly indicate that, depending on the regimen, the larger saccharin amounts caused systemic stress and death. For, though there was no difference in the amount of saccharin consumed by Groups 24SF-S and 12SF-S, F $(1,8)=1.64, \mathrm{p}>.05$, deaths occurred in the 24 - but not in the 12 -h regimen. This suggests that although all animals ate equal amounts of food per $48 \mathrm{~h}$, the more infrequent feeding caused stronger stress (also reflected in the larger body weight loss, Table 1) than that caused by the more frequent feeding cycle. Viewed against these findings, the relatively small saccharin amounts causing systemic overload, i.e., death, in the 48-h group can be reconciled.

Taken together, the findings from the three regimens show that saccharin can cause systemic overload. These systemic effects are more a function of the intermeal interval than of the absolute amount of saccharin. Thus, the amounts can be very high, over $5 \mathrm{mg} / \mathrm{g}$ of body weight, yet cause no systemic overload, as in Group 12SF-S. On the other hand, the amounts can be quite low, below $2 \mathrm{mg} / \mathrm{g}$ of body weight, as in Groups $48 \mathrm{~F}-\mathrm{S}$ and $48 \mathrm{~F}-\mathrm{SvW}$, and cause rapid systemic stress and death. Neither salt ${ }^{1}$ nor extreme amounts of water, $90 \mathrm{ml} / 24 \mathrm{~h}$, instead of $22.5 \mathrm{ml} / 24 \mathrm{~h}$ drunk by the controls (Volo \& Strouthes, 1974), can lead to death.

Though, in general, intermeal interval and body weight loss seemed related, there is no evidence of a causal relation between body weight loss and death in animals on the longer intermeal intervals. For example, saccharin animals on the 48 -h food regimen died at mean body weights which were higher than those by the rats on the 24 -h regimen. Saccharin animals on the 12-h regimen survived, yet their body weights were considerably lower as also were those of the animals on water and 48-h food regimen. Finally, in a recent experiment, $100 \%$ of the animals on water and a 48 -h food regimen survived at mean $51 \%$ body weight by the end of the 144-day experiment.

Aside from its implications in the saccharin-cancer debate this study yielded strong additional evidence that saccharin can produce systemic stress under certain deprivation and, by inference, perhaps even under nondeprivation conditions. Thus, its potential dangers to dieting individuals who eat infrequently 
and consume saccharin in diet-drinks cannot be minimized.

In view of these results, inferences based on behavior studies which involve animals fed saccharin on schedules approximating the ones in this study on the assumption that saccharin elicits a sweet sensation, acts as a reinforcer but is otherwise physiologically inert need to be reviewed.

\section{REFERENCE NOTE}

1. Arnold, D. L., Moodie, C. A., Grice, H. C., Charbouneau, S. M., Stavric, B., \& Munro, I. C. Long term toxicity of orthotoluenesulfonamide and saccharin in the rat. Paper presented at the Toxicology Forum, The Eppley Institute for Research in Cancer, May 10, 1977.

\section{REFERENCES}

Beebe-Center, J. G., Black, P., Hoffman, A. C., \& Wade, M. Relative per diem consumption as a measure of preference in the rat. Journal of Comparative and Physiological Psychology, 1948, 41, 239-251.

Bryan, G. T., Erturk, E., \& Yoshida, O. Production of mouse bladder carcinomas in mice by sodium saccharin. Science, 1970, 68, 1238-1240.

Bundle, C. A., \& LACKEY, R. W. Failure of oral saccharin to influence blood sugar. Proceedings for the Society of Experimental Biology and Medicine, 1948, 68, 581-582.

Carlson, A. J., Eldridge, C. J., Martin, H. P., \& Foran, F. L. Studies on the physiological action of saccharin. Journal of Metabolic Research, 1923, 3, 451.

Folin, O. Preservatives and other chemicals in food: Their use and abuse. Cambridge: Harvard University Press, 1914.
Haramaki, K. Ueber den Einfluss des Saccharins auf einige Funkitionen des Verdaungs-apparats und der Nieren. Zeitschrift für physikalisch und diaetetik Therapie, 1922, 26, 183-186.

HERTER, C. A. The action of sodium benzoate and benzoic acid on the human organism. New York: Author, 1910.

Kun, E., \& Istvan, H. The influence of oral saccharin on blood sugar. Proceedings for the Society of Experimental Biology and Medicine, 1947, 66, 175-177.

STRouthes, A. Long-range two choice saccharin and water consumption in rats. Journal of Comparative and Physiological Psychology, 1970, 73, 123-124.

Strouthes, A. Saccharin drinking and mortality in rats. Physiol: ogy \& Behavior, 1973, 10, 781-791.

VALENSTEIN, E. S. The significance of sodium in the preference for saccharin solutions. Psychonomic Science, 1966, 5, 341-342.

VAlenstein, E. S., \& Weber, M. L. Potentiation of insulin coma by saccharin. Journal of Comparative and Physiological Psychology, 1965, 60, 443-446.

Volo, A., \& Strouthes, A. Saccharin ingestion, weight loss, and mortality in rats. Physiological Psychology, 1974, 2, 323-325.

W ARREN, R. P., \& W ARREN, R. M. Soluable saccharin preference: A nutritive basis for persistence. Nature, 1966, 210, 310-311.

\section{NOTE}

1. In an unpublished experiment using procedures identical to the ones used in this study, 10 female and 9 male albino rats were fed 8 and $10 \mathrm{~g}$ of food per $24 \mathrm{~h}$, respectively, and drank $1.5 \%$ salt solution for $\mathbf{4 8}$ days. They drank abnormally large amounts of solution and, as expected, lost weight but no deaths occurred.

(Received for publication May 25, 1977; revision accepted August 24, 1977.) 